\title{
Review Article,
}

\author{
Association of Obesity and Covid-19 Severity: The Systematic \\ Review \\ Daniel Setiawan Nathan ${ }^{1}$, Hoo Yumilia ${ }^{2}$ \\ ${ }^{1,2}$ Division of Endocrine Metabolic Diabetes Departement of Internal Medicine \\ Faculty of Medicine Maranatha Christian University/Immanuel Hospital \\ Email Address: dokterdaniel@gmail.com
}

\begin{abstract}
:
Introduction: Obesity is a common, serious, and costly chronic disease. Having obesity puts people at risk for many other serious chronic diseases and increases the risk of severe illness from COVID-19. This study was designed to collect data on the association between obesity and severity of COVID-19.

Methods: This study is a systematic review. We searched for the keywords "coronavirus disease 2019" or "covid-19" or "2019 novel coronavirus" or "2019-ncov" or "novel coronavirus 2019 infection" or "2019ncov infection" or "severe acute respiratory syndrome coronavirus 2" or "sars-cov-2") and "obesity" or "overweight" or "body mass index" or "BMI" or "visceral fat" or "excessive fat" or "abdominal fat" or "visceral adipose tissue" or "visceral adiposity" or "central adiposity" or "waist circumference" or "risk factors" or "factor" or "risk factor" or "clinical characteristics" or "clinical features". The study included in this is research that focuses on the relationship between obesity and severity of COVID-19. The inclusion criteria of the research that will be included are studies that examine the relationship between obesity and severity of COVID-19, with adult subjects (not animal studies), research conducted within the last ten years and using primary data. The purpose of this study was to examine the relationship between obesity and severity of COVID-19.

Results: We found several relevant journals or articles related to the relationship between obesity and severity of COVID-19. The search results in the Pubmed journal database; we found one journal that discusses the relationship between obesity and severity of COVID-19. A Google scholar search shows five studies relevant to this study.

Conclusion: Obesity in many studies has been associated with the severity of COVID-19. There are several possible pathways that are thought to cause this severity. First, obesity is associated with altered inflammatory performance. Second, obesity is associated with other comorbidities.
\end{abstract}

Keywords: Body Mass Index (BMI), COVID-19, Obesity.

\section{Introduction:}

Obesity is a chronic condition due to the accumulation of fat in the body is very high. The problem of obesity is increasing in the world. This is a big challenge in preventing the growth of chronic diseases in the world. Obesity is also triggered by industrial and economic growth, as well as lifestyle changes, increased intake of nutrients from processed foods, or high-calorie diets. ${ }^{1}$ BMI provides the most useful populationlevel measure of overweight and obesity as it is the same for both sexes and for all ages of adults. However, it should be considered a rough guide because it may not correspond to the same degree of fatness in different individuals. Based on WHO data in 2016, about 650 million adults are obese, while 340 million children and adolescents aged 5 to 19 years are overweight. ${ }^{2}$ Study has shown that obesity can suppress the immune system, thereby making individuals susceptible to infectious diseases. Obesity has emerged as a strong risk factor for the severity of COVID-19 during the pandemic. Several 
studies have shown that individuals with COVID-19 and obesity have an increased risk of severe illness, hospitalization, and death. ${ }^{3,4}$ A prospective community-based cohort study highlights that a body mass index greater than $23 \mathrm{~kg} / \mathrm{m} 2$ is associated with an increased risk of severe COVID19 outcomes, especially in patients younger than 40 years. This large population-based study corroborates the evidence that obesity is a major risk factor associated with adverse outcomes in patients with COVID-19. ${ }^{3-5}$ Obesity is a common, serious, and costly chronic disease. Having obesity puts people at risk for many other serious chronic diseases and increases the risk of severe illness from COVID-19. This study was designed to collect data on the association between obesity and severity of COVID-19.

\section{Table1. Search results}

\begin{tabular}{|c|c|c|c|c|c|c|}
\hline Author & Origin & Method & $\begin{array}{c}\text { Sample } \\
\text { Size }\end{array}$ & Population & Period & Outcame \\
\hline $\begin{array}{l}\text { Zhu, et al } \\
(\mathbf{2 0 2 0})^{7}\end{array}$ & UK & Cohort study & $\begin{array}{c}489.769 \\
\text { patient }\end{array}$ & $\begin{array}{l}\text { The exposures } \\
\text { of interest are } \\
\text { BMI categories } \\
\text { and central } \\
\text { obesity (e.g., } \\
\text { larger waist } \\
\text { circumference). }\end{array}$ & $\begin{array}{c}\text { March-April } \\
2020\end{array}$ & $\begin{array}{l}\text { Compared to adults with normal } \\
\text { weight, those with a higher BMI } \\
\text { had a dose-response increases in } \\
\text { the risk of severe COVID-19, with } \\
\text { the following adjusted ORs: for } \\
25.0-29.9 \mathrm{~kg} / \mathrm{m} 2,1.40 \text { ( } 95 \% \mathrm{CI} \\
1.14-1.73 ; \mathrm{P}=0.002) \text {; for } 30.0- \\
34.9 \mathrm{~kg} / \mathrm{m} 2,1.73 \text { (95\%CI } 1.36- \\
2.20 ; \mathrm{P}<0.001) \text {; for } 35.0- \\
39.9 \mathrm{~kg} / \mathrm{m} 2,2.82 \text { (95\%CI } 2.08- \\
3.83 ; \mathrm{P}<0.001) \text {; and for } \\
\geq 40.0 \mathrm{~kg} / \mathrm{m} 2,3.30 \text { (95\%CI } 2.17- \\
5.03 ; \mathrm{P}<0.001) \text {. Likewise, central } \\
\text { obesity was associated with } \\
\text { significantly higher risk of severe } \\
\text { COVID-19 (P }<0.001) \text {. }\end{array}$ \\
\hline $\begin{array}{l}\text { Gao, et al } \\
(2020)^{9}\end{array}$ & China & Cohort study & $\begin{array}{c}150 \\
\text { patients }\end{array}$ & $\begin{array}{l}\text { Adult patients } \\
\text { with COVID- } \\
19\end{array}$ & $\begin{array}{l}17 \text { January } \\
\text { and } 11 \\
\text { February } \\
2020\end{array}$ & $\begin{array}{l}\text { In the logistic regression analyses, } \\
\text { the presence of obesity was } \\
\text { associated with an approximately } \\
\text { threefold increased risk of having } \\
\text { severe COVID-19 (unadjusted } \\
\text { odds ratio [OR] } 2.91,95 \% \text { CI } \\
1.31-6.47 \text { ). Each 1-unit increase } \\
\text { in BMI was also associated with a } \\
12 \% \text { increase in the risk of severe } \\
\text { COVID-19 (unadjusted OR } 1.12 \text {, } \\
95 \% \text { CI } 1.01-1.23 \text { ). Notably, the } \\
\text { association between obesity and } \\
\text { greater COVID-19 severity } \\
\text { remained significant even after } \\
\text { adjusting for age, sex, smoking } \\
\text { status, hypertension, diabetes, and } \\
\text { dyslipidemia (adjusted OR 3.00, } \\
95 \% \text { CI } 1.22-7.38 \text { for obesity, and } \\
\text { adjusted OR 1.13, } 95 \% \text { CI } 1.01- \\
1.28 \text { for BMI). }\end{array}$ \\
\hline $\begin{array}{l}\text { Kang et al } \\
(2021)^{8}\end{array}$ & $\begin{array}{l}\text { South } \\
\text { Korea }\end{array}$ & $\begin{array}{l}\text { Retrospective } \\
\text { study }\end{array}$ & $\begin{array}{c}4.141 \\
\text { patient }\end{array}$ & $\begin{array}{l}\text { COVID-19 } \\
\text { patients who } \\
\text { were released } \\
\text { from isolation } \\
\text { or had died }\end{array}$ & $\begin{array}{l}\text { Untul April } \\
30,2020\end{array}$ & $\begin{array}{l}\text { Among participants, those with a } \\
\text { BMI of } 18.5-22.9 \mathrm{~kg} / \mathrm{m} 2 \text { were the } \\
\text { most common }(42.0 \%), \text { followed } \\
\text { by } 25.0-29.9 \mathrm{~kg} / \mathrm{m} 2(24.4 \%), \\
23.0-24.9 \mathrm{~kg} / \mathrm{m} 2(24.3 \%), \geq 30 \\
\mathrm{~kg} / \mathrm{m} 2(4.7 \%) \text {, and }<18.5 \mathrm{~kg} / \mathrm{m} 2 \\
(4.6 \%) . \text { In addition, } 1,654(41.2 \%) \\
\text { were men and } 3.04 \% \text { were } \\
\text { fatalities. Multivariable analysis } \\
\text { showed that age, male sex, BMI < } \\
18.5 \mathrm{~kg} / \mathrm{m} 2, \text { BMI } \geq 25 \mathrm{~kg} / \mathrm{m} 2, \\
\text { diabetes mellitus, chronic kidney }\end{array}$ \\
\hline
\end{tabular}




\begin{tabular}{|c|c|c|c|c|c|c|}
\hline & & & & & & $\begin{array}{l}\text { disease, cancer, and dementia } \\
\text { were independent risk factors for } \\
\text { fatal illness. In particular, BMI < } \\
18.5 \mathrm{~kg} / \mathrm{m} 2 \text { (odds ratio [OR] } 3.97 \text {, } \\
95 \% \text { CI } 1.77-8.92), 25.0-29.9 \\
\mathrm{~kg} / \mathrm{m} 2(2.43,1.32-4.47) \text {, and } \geq 30 \\
\mathrm{~kg} / \mathrm{m} 2(4.32,1.37-13.61) \text { were } \\
\text { found to have higher ORs than the } \\
\text { BMI of } 23.0-24.9 \mathrm{~kg} / \mathrm{m} 2 \\
\text { (reference). There was no } \\
\text { significant difference between } \\
\text { those with a BMI of } 18.5-22.9 \\
\mathrm{~kg} / \mathrm{m} 2(1.59,0.88-2.89) \text { and } 23.0- \\
24.9 \mathrm{~kg} / \mathrm{m} 2 .\end{array}$ \\
\hline $\begin{array}{l}\text { Cai Q, et al } \\
(2020)^{10}\end{array}$ & China & $\begin{array}{l}\text { Cohort } \\
\text { prospective } \\
\text { study }\end{array}$ & $\begin{array}{c}383 \\
\text { patient }\end{array}$ & $\begin{array}{l}\text { COVID-19 } \\
\text { patient }\end{array}$ & $\begin{array}{c}\text { January } 11 \\
\text { until } \\
\text { February } 16, \\
2020\end{array}$ & $\begin{array}{l}\text { Obese patients tended to have } \\
\text { symptoms of cough }(\mathrm{P}=0.03) \text { and } \\
\text { fever }(\mathrm{P}=0.06) \text { compared with } \\
\text { patients who were not obese. } \\
\text { Compared with normal weight } \\
\text { patients, those who were } \\
\text { overweight had } 1.84 \text {-fold odds of } \\
\text { developing severe COVID-19 } \\
\text { (odds ratio [OR] 1.84, 95\% CI } \\
0.99-3.43, \mathrm{P}=0.05) \text {, while those } \\
\text { who were obese were at } 3.40 \text {-fold } \\
\text { odds of developing severe disease } \\
\text { (OR 3.40, 95\% CI 1.40-2.86, P = } \\
0.007) \text {, after adjusting for age, } \\
\text { sex, epidemiological } \\
\text { characteristics, days from disease } \\
\text { onset to hospitalization, presence } \\
\text { of hypertension, diabetes, } \\
\text { cardiovascular disease, chronic } \\
\text { obstructive pulmonary disease, } \\
\text { liver disease, and cancer, and drug } \\
\text { used for treatment. Additionally, } \\
\text { after similar adjustment, men who } \\
\text { were obese versus those who were } \\
\text { normal weight were at increased } \\
\text { odds of developing severe } \\
\text { COVID-19 (OR 5.66, 95\% CI } \\
1.80-17.75, \mathrm{P}=0.003) .\end{array}$ \\
\hline $\begin{array}{l}\text { Moriconi et } \\
\text { al (2020) }\end{array}$ & Italy & $\begin{array}{c}\text { Cohort } \\
\text { prospective }\end{array}$ & $\begin{array}{c}100 \\
\text { patient }\end{array}$ & $\begin{array}{l}\text { Patients with } \\
\text { COVID-19 } \\
\text { pneumonia }\end{array}$ & $\begin{array}{c}\text { March 16th } \\
\text { and April } \\
15 \text { th, } 2020\end{array}$ & $\begin{array}{l}\text { Patients with }(\mathrm{OB}, 29) \text { and without } \\
\text { obesity (N-OB, } 71) \text { were similar in } \\
\text { age, gender and comorbidities, with } \\
\text { the exception of hypertension that } \\
\text { was more frequent in OB group. At } \\
\text { admission, inflammatory markers } \\
\text { were higher in OB than N-OB } \\
\text { group. OB group showed a worse } \\
\text { pulmonary clinical picture, with } \\
\text { lower PaO2 }(57 \pm 15 \text { vs. } 68 \pm 14 \\
\text { mmHg, } \mathrm{p}=0.042) \text {, and SaO2 ( } 88 \pm \\
6 \mathrm{vs} .92 \pm 5 \%, \mathrm{p}=0.049) \text { at } \\
\text { admission consequently requiring } \\
\text { higher volumes of oxygen (Fi02: } 38 \\
\pm 15 \text { vs. } 29 \pm 19 \%, \mathrm{p}=0.047) \text { and a } \\
\text { longer period to achieve oxygen } \\
\text { weaning }(10 \pm 6 \text { vs. } 15 \pm 7 \text { days, } \mathrm{p} \\
=0.03) . \mathrm{OB} \text { group also had positive } \\
\text { swabs for longer time }(19 \pm 8 \text { vs. } 13 \\
\pm 7, \text { days, } \mathrm{p}=0.002) \text {, and required } \\
\text { longer hospital stay }(21 \pm 8 \text { vs. } 13 \pm \\
8, \text { days, } \mathrm{p}=0.0008) \text {. }\end{array}$ \\
\hline
\end{tabular}




\begin{tabular}{|c|c|c|c|c|c|c|}
\hline $\begin{array}{l}\text { Sahin et al } \\
(2021)^{12}\end{array}$ & Turkey & $\begin{array}{c}\text { Cross } \\
\text { sectional }\end{array}$ & $\begin{array}{c}675 \\
\text { patient }\end{array}$ & $\begin{array}{l}\text { Patients who } \\
\text { were admitted } \\
\text { to COVID-19 } \\
\text { outpatient } \\
\text { clinics at the } \\
\text { Cerrahpaşa } \\
\text { Medical } \\
\text { Faculty and } \\
\text { Koç University } \\
\text { School of } \\
\text { Medicine } \\
\text { Hospitals }\end{array}$ & $\begin{array}{c}\text { March until } \\
\text { August } 2020\end{array}$ & $\begin{array}{l}\text { COVID-19 patients with } \\
\text { overweight and obesity presented } \\
\text { with more severe clinical findings. } \\
\text { Health-care providers should take } \\
\text { into account that people living with } \\
\text { overweight and obesity are at } \\
\text { higher risk for COVID-19 and its } \\
\text { complications. }\end{array}$ \\
\hline
\end{tabular}

\section{Method:}

This study is a systematic review. Source of this study data comes from literature obtained through the internet in the form of research results published on the internet, both in Cochrane, PubMed, Google scholar, and other journal databases. We searched for the keywords "coronavirus disease 2019" or "covid-19" or "2019 novel coronavirus" or "2019ncov" or "novel coronavirus 2019 infection" or "2019-ncov infection" or "severe acute respiratory syndrome coronavirus 2" or "sars-cov-2") and "obesity" or "overweight" or "body mass index" or "BMI" or "visceral fat" or "excessive fat" or "abdominal fat" or "visceral adipose tissue" or "visceral adiposity" or "central adiposity" or "waist circumference" or "risk factors" or "factor" or "risk factor" or "clinical characteristics" or "clinical features".

The study included in this is research that focuses on the relationship between obesity and severity of COVID-19. The inclusion criteria of the research that will be included are studies that examine the relationship between obesity and severity of COVID-19, with adult subjects (not animal studies), research conducted within the last ten years and using primary data. The purpose of this study was to examine the relationship between obesity and severity of COVID-19.

\section{Result:}

We found several relevant journals or articles related to the relationship between obesity and severity of COVID-19. The search results in the Pubmed journal database; we found one journal that discusses the relationship between obesity and severity of COVID-19. A Google scholar search shows five studies relevant to this study. Information on all the studies involved in this systematic review can be seen in Table 1 .

\section{Discussion:}

Prevalence of obesity among hospitalized COVID19 patients can reach up to $61.3 \% .^{6}$ More established age is very much perceived as a significant danger factor for creating serious conditions in COVID-19. The instrument basic weight expands the danger of serious COVID-19 is as yet unclear. Focal heftiness is characterized as a condition of unnecessary visceral adipose tissue (VAT) collection. ${ }^{7}$ In Korea cross country study, they showed that $\mathrm{BMI} \geq 25.0 \mathrm{~kg} / \mathrm{m} 2$ was related with an expanded danger for lethal sickness just as basic ailment from COVID-19. ${ }^{8}$

Besides, BMI $<18.5 \mathrm{~kg} / \mathrm{m} 2$ additionally expanded the danger of basic and deadly disease brought about by COVID-19, like that seen with $\mathrm{BMI} \geq 25.0$ $\mathrm{kg} / \mathrm{m} 2$. Consequently, BMI $\geq 25.0 \mathrm{~kg} / \mathrm{m} 2$ and $<18.5$ $\mathrm{kg} / \mathrm{m} 2$ were found to have a relationship with expanded casualty from COVID-19 free of joined comorbidities. Albeit the male sex showed a higher danger of lethal disease from COVID-19, there was no clear proof that BMI had a more adverse impact on men than on ladies in this investigation. ${ }^{8}$

Gao (2020) showed presence of obesity was associated with an approximately threefold increased risk of having severe COVID-19. Each 1unit increase in BMI was also associated with a $12 \%$ increase in the risk of severe COVID-19. Notably, the association between obesity (or increasing BMI values) and greater COVID-19 severity remained significant even after adjusting for age, sex, smoking status, hypertension, diabetes, and dyslipidemia. ${ }^{9}$

Patients with focal corpulence as confirmed by midsection perimeter or midriff to-hip proportion were likewise observed to be bound to create serious COVID-19 $(\mathrm{P}<0.001)$ in an enormous populace based accomplice. ${ }^{7}$ Past research has shown that stoutness is related with more awful results because of contamination and illness movement for particular kinds of irresistible viral sickness, for example, flu in the 1918 "Spanish" flu 
pandemic, the 1957 pandemic, the 1968 pandemic and the H1N1 Influenza An infection (IAV) pandemic in 2009. ${ }^{6}$ The specific systems connecting the noticed weightto extreme COVID19 are logical multifactorial-which come from stoutness related changes in pneumonic physiology and the hereditary qualities to adjustments in resistant reaction and provocative profiles, endothelial brokenness, and metabolic brokenness - and warrant explanation. All the more explicitly, serious heftiness lessens lung consistence, expiratory save volume, and useful lingering limit just as viability of respiratory muscle, prompting expanded respiratory exertion, oxygen utilization, and respiratory energy utilization. $^{13,14}$ Second, ongoing examination has shown the job of hereditary qualities (e.g., qualities identified with cell expansion and incendiary reaction) divided among weight and aspiratory illnesses. ${ }^{15,16}$ The noticed connection between the hereditary relational word to weight and extreme COVID-19 likewise propose the job of hereditary qualities in the pathogenesis of serious COVID-19. Third, arising proof proposes the job of adiposopathy - fat tissue brokenness - in the pathobiology of mind boggling illness conditions including asthma. ${ }^{17}$ Adiposopathy is portrayed by weakened adipogenesis, modified lipid digestion, and fat/fundamental aggravation (e.g., upregulated IL-6 and TH17 pathways, TH1 polarization). ${ }^{17}$ Moreover, exploration of heftiness and dyslipidemia has recommended "preparing" of the lung for ARDS, reflecting enactment of foundational safe reaction as well as lung-occupant cells (e.g., alveolar macrophages, endothelial cells). ${ }^{7}$ Fourth, a new non-COVID-19 investigation additionally exhibited that patients with a higher BMI had higher articulation of ACE2 in their bronchial epithelium, recommending an expanded helplessness to SARSCoV-2 disease in patients with weight. Notwithstanding these possible instruments, the writing has archived that stoutness-especially focal corpulence - is likewise causally connected to other comorbidities (e.g., cardiovascular illness, diabetes, hypertension). ${ }^{7}$ These hidden conditions increment vulnerability to ARDS-related end-organ disappointment. Ultimately, these potential outcomes are not totally unrelated. In any case the intricacy, the recognizable proof of weight and its hereditary inclination as a guilty party of COVID19 dismalness is a significant finding. Our perceptions ought to support future examination unraveling the complicated snare of the microbe, weight, aviation route and fundamental irritation, and COVID-19 pathobiology. ${ }^{7}$ Patients determined to have weight hypoventilation disorder have trademark hypoxemia and hypercapnia, and may experience a higher danger of serious conditions when contaminated with SARS-CoV-2. Along these lines, weight related hypoxemia might be a significant supporter of the seriousness of COVID19 among the people who are large. ${ }^{18}$ This might clarify why large COVID-19 patients are at more serious danger of requiring IMV, as the outcomes in our examination show. Corpulence additionally expands the danger of numerous normal nontransmittable illnesses, for example, diabetes mellitus, cardiovascular problems, malignancy and non-alcoholic greasy liver sickness, and frequently coincides with them in a solitary person. ${ }^{18}$

These existing together diseases are thought to improve the probability of serious sickness from COVID-19 for individuals with weight. Extreme fat tissue including ectopic fat can fill in as a repository for ACE2 and microorganisms, for example, Covid, flu An infection and Mycobacterium tuberculosis. ${ }^{18}$ Past the seriousness of the illness, heftiness expands the term of flu An infection delivery to speed up the spread of the infection, particularly for individual to-individual transmission. ${ }^{18} \mathrm{~A}$ few virological and physiological components that may clarify the job of weight in the pathogenesis of the illness have been recommended. In particular, for COVID-19 patients, the SARS-CoV-2 spike protein has an expanded fondness for human ACE2 contrasted and different vertebrates. ACE2 is profoundly communicated in fat tissue. In the wake of tainting host cells, serine proteases, for example, TMPRSS2 intercede the cleavage of the spike and work with viral section into the cells through endosomes. ${ }^{19}$ The actual infection causes expanded apoptosis of lymphocytes, and hindered capacity of lymphocytes brings about a fulminant cytokine storm, which is portrayed by extreme flowing degrees of IL-6, IL-2, IL-7, TNF $\alpha$, etc. IL-6, for instance, is raised in corpulent COVID-19 patients and has been recommended to be a key proinflammatory factor that triggers the provocative tempest. In accordance with this, the IL-6 blocker tocilizumab has been proposed as a treatment in COVID-19 and could build the lymphocyte blood count of COVID-19 patients. ${ }^{19}$ Versatile invulnerability is additionally upset in stoutness, with a strongly decline in calming CD4+ and CD8+ cells and an expanded level of proinflammatory insusceptible cells, for example, Th17 and Th22 cells. Also, due to the enormous volume of fat tissue, the populace with heftiness had a huge measure of ACE2 and was 
leaned to host and stock a tremendous measure of infection, which in expanded viral shedding, insusceptible inactivation, and cytokine storm. ${ }^{19}$ Likewise, school volunteers with occasional flu indications who have a higher BMI have been found to create more irresistible vapor sprayers. These discoveries may likewise reach out to COVID-19. The mix of fat tissue-interceded resistant and metabolic brokenness may assume a vital part in the pathophysiological pathways by which stoutness influences the guess of COVID-19. ${ }^{18}$ Poor quality foundational irritation and expanded insulin opposition are normal in fat people where these resistant and metabolic marvels are firmly connected with abundance VAT. Abundance VAT is accepted to be a significant reason for the incendiary sickness of corpulence which thus can prompt extreme entanglements other than the viral disease itself, like the advancement of apoplexy. ${ }^{18}$

Moriconi $^{11}$ (2020) showed that inflammatory markers were higher in obesity than non- obesity group. Obesity group showed a worse pulmonary clinical picture, with lower $\mathrm{PaO} 2(57 \pm 15$ vs. $68 \pm$ $14 \mathrm{mmHg}, \mathrm{p}=0.042)$, and $\mathrm{SaO} 2$ (88 \pm 6 vs. $92 \pm$ $5 \%, \mathrm{p}=0.049)$ at admission consequently requiring higher volumes of oxygen (Fi02: $38 \pm 15$ vs. $29 \pm$ $19 \%, \mathrm{p}=0.047$ ) and a longer period to achieve oxygen weaning ( $10 \pm 6$ vs. $15 \pm 7$ days, $p=0.03)$. Obesity group also had positive swabs for longer time $(19 \pm 8$ vs. $13 \pm 7$, days, $\mathrm{p}=0.002)$, and required longer hospital stay $(21 \pm 8$ vs. $13 \pm 8$, days, $\mathrm{p}=0.0008$ ).

Sahin $(2021)^{12}$ included the patients $>18$ years of age, with at least one positive SARS-CoV-2 reverse transcriptase-polymerase chain reaction. Patients were grouped according to body mass index values as normal weight $<25 \mathrm{~kg} / \mathrm{m} 2$ (Group A), overweight from 25 to $<30 \mathrm{~kg} / \mathrm{m} 2$ (Group B), Class I obesity 30 to $<35 \mathrm{~kg} / \mathrm{m} 2$ (Group C), and $\geq 35 \mathrm{~kg} / \mathrm{m} 2$ (Group D). Mortality, clinical outcomes, laboratory parameters, and comorbidities were compared among 4 groups.

There showed no significant difference among study groups in terms of mortality. Noninvasive mechanical ventilation requirement was higher in group $\mathrm{B}$ and $\mathrm{D}$ than group $\mathrm{A}$, while it was higher in Group D than Group C (Group B vs. Group A [p = 0.017], Group D vs. Group A [p $=0.001]$, and Group D vs. Group C $[p=0.016])$. Lung involvement was less common in Group A, and presence of hypoxia was more common in Group D (Group B vs. Group A [p $=0.025]$, Group D vs. Group A [p $<0.001]$, Group D vs. Group B [p = 0.006], and Group D vs. Group C $[\mathrm{p}=0.014]){ }^{12}$
The hospitalization rate was lower in Group A than in the other groups; in addition, patients in Group D have the highest rate of hospitalization (Group B vs. Group A [p $<0.001]$, Group C vs. Group A [p < 0.001], Group D vs. Group A [p < 0.001], Group D vs. Group B [p < 0.001], and Group D vs. Group C $[\mathrm{p}=0.010]) .{ }^{12}$ Cai, et al (2020) showed that obese patients had increased odds of progressing to severe COVID-19. As the severe acute respiratory syndrome coronavirus 2 may continue to spread worldwide, clinicians should pay close attention to obese patients, who should be carefully managed with prompt and aggressive treatment. ${ }^{10}$ Conclusion, Obesity in many studies has been associated with the severity of COVID-19. There are several possible pathways that are thought to cause this severity. First, obesity is associated with altered inflammatory performance. Second, obesity is associated with other comorbidities.

\section{$\underline{\text { References: }}$}

[1] Kasper; Denis L; et al. Harrison's Principles of Internal Medicine 19th Edition. New York: McGraw-Hill Education; 2018.

[2] World Health Organization's. Obesity and overweight [Internet]. News-Room. 2021 [dikutip 8 September 2021]. Tersedia pada: https://www.who.int/news-room/factsheets/detail/obesity-and-overweight

[3] Mohammad S, Aziz R, Al Mahri S, et al. Obesity and COVID-19: what makes obese host so vulnerable? Immun Ageing. 2021; 18(1):17-22.

[4] Gao M, Piernas C, Astbury NM, et al. Associations between body-mass index and COVID-19 severity in 6.9 million people in England: a prospective, community-based, cohort study. Lancet Diabetes Endocrinal. 2021;9:350-9.

[5] Kwok S, Adam S, Ho JH, et al. Obesity: A critical risk factor in the COVID-19 pandemic. Clin Obes. 2020;10(6):236-9.

[6] Pettit NN, MacKenzie EL, Ridgway J, et al. Obesity is associated with increased risk for mortality among hospitalized patients with COVID-19. Obesity. 2020;

[7] Zhu Z, Hasegawa K, Ma B, et al. Association of obesity and its genetic predisposition with the risk of severe COVID-19: Analysis of population-based cohort data. Metabolism. 2020;112.

[8] Kang IS, Kong KA. Body mass index and severity/fatality from coronavirus disease 
2019: A nationwide epidemiological study in Korea. PLoS One. 2021;22(8):91-9.

[9] Gao F, Zheng KI, Wang XB, et al. Obesity Is a Risk Factor for Greater COVID-19 Severity. Diabetes Care. 2020;43(7):72-4.

[10] Cai Q, Chen F, Wang T, et al. Obesity and COVID-19 Severity in a Designated Hospital in Shenzhen, China. Diabetes Care. 2020;43(7):1392-8.

[11] Moriconi D, Masi S, Rebelos E, et al. Obesity prolongs the hospital stay in patients affected by COVID-19, and may impact on SARSCOV-2 shedding. Obes Res Clin Pr. 2020;14(3):205-9.

[12] Sahin S, Sazer H, Cicek E, et al. The Role of Obesity in Predicting the Clinical Outcomes of COVID-19. Karger Publ. 2021;

[13] Sattar N, McInnes IB, McMurray JJV. Obesity a risk factor for severe COVID-19 infection: multiple potential mechanisms. Circulation. 2020;142(1):4-6.

[14] Mafort TT, Rufino R, Costa $\mathrm{CH}$, et al. Obesity: systemic and pulmonary complications, biochemical abnormalities, and impairment of lung function. Multidiscip Respir Med. 2016;11(28).

[15] Zhu Z, Guo Y, Shi H, et al. Shared genetic and experimental links between obesityrelated traits and asthma subtypes in UK Biobank. J Allergy Clin Immunol. 2020;145:537-49.

[16] Hobbs BD, de Jong K, Lamontagne M, et al. Genetic loci associated with chronic obstructive pulmonary disease overlap with loci for lung function and pulmonary fibrosis. Nat Genet. 2017;49:426-32.

[17] Peters U, Suratt BT, Bates JHT, et al. Beyond BMI: obesity and lung disease. Chest. 2018;153:702-9.

[18] Huang Y, Lu Y, Huang YM, et al. Obesity in patients with COVID-19: a systematic review and meta-analysis. Metabolism. 2020;10(16):21-8.

[19] Chu Y, Yang J, Shi J, et al. Obesity is associated with increased severity of disease in COVID-19 pneumonia: a systematic review and meta-analysis. Eur J Med Res. 2020;16(7):21-9. 